\title{
Alzheimer's disease CSF biomarkers: clinical indications and rational use
}

\author{
Ellis Niemantsverdriet ${ }^{1} \cdot$ Sara Valckx $^{1} \cdot$ Maria Bjerke $^{1} \cdot$ Sebastiaan Engelborghs $^{1,2}$ (1)
}

Received: 20 April 2017 / Accepted: 12 July 2017/Published online: 27 July 2017

(c) The Author(s) 2017. This article is an open access publication

\begin{abstract}
This review focusses on the validation and standardization of Alzheimer's disease (AD) cerebrospinal fluid (CSF) biomarkers, as well as on the current clinical indications and rational use of CSF biomarkers in daily clinical practice. The validated AD CSF biomarkers, $A \beta_{1-}$ ${ }_{42}$, T-tau, and P-tau ${ }_{181}$, have an added value in the (differential) diagnosis of $\mathrm{AD}$ and related disorders, including mixed pathologies, atypical presentations, and in case of ambiguous clinical dementia diagnosis. CSF biomarkers should not be routinely used in the diagnostic work-up of dementia and cannot be used to diagnose non-AD dementias. In cognitively healthy subjects, CSF biomarkers can only be applied for research purposes, e.g., to identify pre-clinical $\mathrm{AD}$ in the context of clinical trials with potentially disease-modifying drugs. Therefore, biomarkerbased early diagnosis of $\mathrm{AD}$ offers great opportunities for preventive treatment development in the near future.
\end{abstract}

Keywords Alzheimer's disease $\cdot$ Cerebrospinal fluid . Biomarkers · Dementia $\cdot$ Amyloid- $\beta$ - Tau

Joint last authors: Maria Bjerke, Sebastiaan Engelborghs.

Sebastiaan Engelborghs

Sebastiaan.Engelborghs@uantwerp.be

1 Reference Center for Biological Markers of Dementia (BIODEM), Laboratory of Neurochemistry and Behavior, Institute Born-Bunge, University of Antwerp (UAntwerp), Antwerp, Belgium

2 Department of Neurology and Memory Clinic, Hospital Network Antwerp (ZNA) Middelheim and Hoge Beuken, Antwerp, Belgium

\section{Introduction}

The Alzheimer continuum: a new concept that has an impact on diagnosis, prevention, and treatment strategies

The most common type of dementia is Alzheimer's disease (AD), affecting up to $60-70 \%$ of dementia cases and exponentially increasing in prevalence with age. $\mathrm{AD}$ has a long pre-clinical phase, in which neuropathological changes develop, starting at least a decade before symptom onset. At onset, complaints are insidious and mild. Subjective cognitive decline (SCD) refers to cognitive symptoms that cannot be confirmed by a neuropsychological assessment. Patients who show subtle deficits in performing daily activities in combination with objective cognitive dysfunction, confirmed by neuropsychological assessment, have reached a stage of the so-called mild cognitive impairment (MCI). If $\mathrm{MCI}$ is due to $\mathrm{AD}$, a progressive cognitive deterioration can lead to certain functional deficits which characterize the $\mathrm{AD}$ dementia stage with a progression rate of $20-40 \%$ in MCI patients [1-4]. Therefore, $\mathrm{AD}$ is described as a continuum and includes a pre-clinical phase, SCD [5], MCI [6], and dementia due to $\mathrm{AD}$ [7]. In the past, the diagnosis of $\mathrm{AD}$ could only be suggested when the dementia stage was reached. Due to major advances in biomarker-based research, it is now possible to detect $\mathrm{AD}$-related changes well before the onset of the first clinical symptoms. This provides researchers an exceptional window for early diagnosis, treatment, and prevention strategies. The cerebrospinal fluid (CSF) offers a window to the brain as the brain's metabolism and pathology is reflected in the CSF that can easily be collected through a lumbar puncture (LP), which is a safe and well-tolerated procedure $[8,9]$. This review focusses on the 
validation and standardization of AD CSF biomarkers, as well as on the current clinical indications and rational use of CSF biomarkers in daily clinical practice.

\section{The diagnosis of Alzheimer's disease relies on different biomarker categories: amyloid-B deposition, neurofibrillary tangles, and neuronal degeneration}

The clinical diagnosis of $\mathrm{AD}$ is often made in accordance with the criteria from the National Institute of Neurological and Communicative Disorders and Stroke-Alzheimer's Disease and Related Disorders Association (NINCDS-ADRDA), originating from 1984 [10]. These criteria are mainly based on excluding other systemic and brain disorders that could account for cognitive deterioration confined to the dementia stage and result at best in a diagnosis of probable AD. A clinical diagnosis of probable $\mathrm{AD}$ based on these criteria has been shown to achieve an average sensitivity and specificity of 81 and $70 \%$, respectively [11]. A promising tool to increase the diagnostic accuracy of $\mathrm{AD}$ is the use of CSF biomarkers [7, 12-14] that can be measured in the CSF after an LP. If performed correctly, LP has a low complication rate, a high diagnostic yield, and is usually more tolerable than subjects expect [8, 9]. Biomarkers that reflect the pathology of $\mathrm{AD}$ already show abnormal concentrations in the pre-clinical stage of $\mathrm{AD}$, thus allowing early $\mathrm{AD}$ diagnosis [15], even before the onset of symptoms. In 1998, a consensus report was published by the Working Group on Molecular and Biochemical Markers of Alzheimer's Disease that determined the requirements for an ideal diagnostic biomarker for $\mathrm{AD}$ [16]. In general, biomarkers should be able to detect a fundamental feature of AD pathology. The value of biomarkers should also be demonstrated in neuropathologically confirmed subjects as neuropathology is still considered the gold standard for AD diagnosis. Diagnostic accuracy, sensitivity, and specificity levels should be above $80 \%$. The test itself should be reliable and reproducible, non-invasive, simple to perform, and inexpensive [16].

CSF biomarkers are preferred over blood/plasma biochemical markers in $\mathrm{AD}$ to reflect brain pathophysiology, because the brain (interstitial fluid) is in direct contact with the CSF by unrestricted bi-directional flow of proteins and the CSF is secluded from direct impact of the peripheral system through the restricted transportation of molecules and proteins by the blood-CSF barrier [17]. Therefore, CSF analysis is valuable to detect markers of neurodegenerative diseases in vivo. CSF biomarkers are related to the three main pathological changes that occur in the AD brain (Table 1): amyloid- $\beta(\mathrm{A} \beta)$ deposition into extracellular A $\beta$ plaques, intracellular neurofibrillary tangles (NFT) formation, and neuronal loss. The $\beta$-amyloid peptide composed of 42 amino acids $\left(A \beta_{1-42}\right)$ is the result of the cleavage of transmembrane amyloid precursor protein (APP) by $\beta$ - and $\gamma$-secretases. $A \beta_{1-42}$ is highly insoluble and aggregates into extracellular $A \beta$ deposits in the $\mathrm{AD}$ brain, detected as decreased CSF $\mathrm{A} \beta_{1-42}$ concentrations in AD. Tau proteins are abundantly present in the cytosol of neurons, where they function to stabilize microtubules. In $\mathrm{AD}$, an imbalance between kinases and phosphatases results in a hyperphosphorylation of tau, which leads to detachment of tau from microtubules and to its accumulation into NFT. During the neurodegenerative process, tau and phosphorylated tau proteins are also released into the extracellular space, resulting in increased CSF tau concentrations in AD. The formation of plaques and NFT promotes neuronal injury and, consequently, neuronal and synaptic degeneration in $\mathrm{AD}$. The first $\mathrm{A} \beta$ plaques occur at least 10 years, and probably 20-30 years before the first symptoms [18], and are as such detectable in the CSF for early diagnosis. CSF tau biomarkers change later in the pathophysiological process compared to CSF $\mathrm{A} \beta_{1-42}[19,20]$ and CSF tau is stronger correlated with cognitive decline than $\mathrm{A} \beta_{1-42}[20,21]$. CSF biomarkers give a complete overview of AD pathophysiology, and in addition, an LP is highly accessible with a low cost price, in contrast to the imagingbased markers used in AD diagnosis (Table 1). These imaging-based biomarkers include positron emission tomography (PET) with amyloid-specific probes (marker for $A \beta$ deposition) or tau tracers (marker for neuronal injury), quantification of decreased metabolism in affected brain regions with fluorodeoxyglucose (FDG) PET imaging (marker for neuronal injury), quantification of the brain perfusion in affected brain regions with single photon emission computed tomography (SPECT) (marker for neuronal injury), and the analysis of volumetric magnetic resonance imaging (MRI) with determination of hippocampal or medial temporal lobe atrophy (marker for neuronal injury) [22-25].

A lot of progress has been made over the past decades to improve AD diagnosis and to validate AD CSF biomarkers in autopsy-confirmed dementia patients [26], resulting in biomarker-based research diagnostic criteria as a growing body of evidence shows that AD CSF biomarkers are reliable, reproducible, and valid as well as suitable for cutoff scores, sensitive, and specific for $\mathrm{AD}$ (differential) diagnosis [13]. Therefore, revised criteria of both the National Institute on Aging/Alzheimer's Association (NIA-AA) [7, 12, 14] and the International Working Group (IWG) [13] include CSF AD biomarkers in the clinical diagnostic work-up. 
Table 1 Overview of the different biomarkers based on the neuropathological changes in Alzheimer's disease

\begin{tabular}{lll}
\hline Pathological change & Biomarker category & Biomarker(s) \\
\hline $\mathrm{A} \beta$ deposition $=$ early marker & Biochemical $(\mathrm{CSF})$ & $\mathrm{CSF} \mathrm{A} \beta_{1-42}$ or $\mathrm{A} \beta_{1-42} / \mathrm{A} \beta_{1-40}$ \\
& Molecular imaging & PET with amyloid-specific probes \\
NFT formation & Biochemical $(\mathrm{CSF})$ & $\mathrm{CSF}$ P-tau ${ }_{181}$ \\
Neuronal injury $=$ downstream & Biochemical $(\mathrm{CSF})$ & $\mathrm{CSF}$ T-tau \\
& Topographical & {$\left[{ }^{18} \mathrm{~F}\right] \mathrm{FDG}-\mathrm{PET}$} \\
& & SPECT \\
& & HCV / MTL atrophy on MRI \\
\hline
\end{tabular}

$A \beta$ amyloid- $\beta, A \beta_{1-42} \beta$-amyloid peptide of 42 amino acids, CSF cerebrospinal fluid, FDG fluorodeoxyglucose, $H C V$ hippocampal volume, $M T L$ medial temporal lobe, $M R I$ magnetic resonance imaging, PET positron emission tomography, $P-t_{10 u}$ 181 phosphorylated tau at threonine 181, SPECT single photon emission computed tomography, $T$-tau total tau protein

\section{Combining biomarkers to increase diagnostic accuracy}

CSF $A \beta_{1-42}$ (marker for $A \beta$ deposition), total tau protein (T-tau; marker for neuronal injury), and phosphorylated tau at threonine $181\left(\mathrm{P}-\right.$ tau $_{181}$; marker for NFT) are validated and integrated CSF biomarkers in the revised diagnostic criteria of $\mathrm{AD}[7,12-14,27]$. Changes in these three core CSF biomarkers allow diagnosing AD already in its prodromal stage [28]. Having all three biomarkers in the normal range rules out $\mathrm{AD}$. Intermediate conditions require further patient follow-up [29]. The concentration of $A \beta_{1-42}$ decreases over time in $\mathrm{AD}$ subjects, while $\mathrm{P}-\operatorname{tau}_{181}$ and T-tau concentrations increase in AD patients compared to healthy controls (including patients with psychiatric disorders like depression) [27]. These biomarker changes almost reach their maximum in the beginning of the symptomatic phase of $\mathrm{AD}$, limiting their predictive value for cognitive decline [30]. The combined use of $A \beta_{1-42}$, $\mathrm{T}$-tau, and P-tau ${ }_{181}$, each essential in the biomarker panel, has the highest diagnostic power to discriminate between $\mathrm{AD}$ and cognitively healthy controls $[13,26]$, with a sensitivity and specificity reaching 92 and $89 \%$, respectively [31]. Another model based on $\mathrm{A} \beta_{1-42}$ and $\mathrm{T}$-tau was developed that could accurately discriminate $\mathrm{AD}$ from controls by means of a discrimination line, which has been validated in clinical practice [32] and in autopsy-confirmed patients with sensitivity levels of $100 \%$ and specificity of $91 \%$ [26].

\section{Diagnostic accuracy is independent from the analytical platform}

CSF A $\beta$ and tau proteins can be measured reliably with several analytical techniques such as single-analyte ELISAs or multi-analyte tests based on xMAP technology. Multiple studies have shown that the diagnostic accuracy of the CSF biomarker concentrations is similar when analytes are measured by means of a multi-analyte assay or single-analyte ELISA tests [33, 34]. These studies show that the clinical value of biomarkers is independent of the method by which concentrations are determined.

\section{The Alzheimer's disease cerebrospinal fluid biomarker panel}

\section{Standardization and harmonization efforts}

Much effort has been put in the standardization and harmonization of AD CSF biomarker analysis and interpretation. The overall goal of all these projects is (1) to detect $\mathrm{AD}$ at the earliest stage possible and identify ways to track the disease through biomarkers, (2) to support advances in $\mathrm{AD}$ intervention, prevention, and treatment (through new diagnostic methods), and (3) to centralize data access.

The EU Joint Programme Neurodegenerative Disease Research (JPND) consortium 'Biomarkers for AD and Parkinson's Disease (PD)' (BIOMARKAPD) Project (2012-2015) aimed in developing certified reference materials to harmonize assays by reducing inter-variability across international centers [35]. In this regard, the BIOMARKAPD project has united many European countries and Canada, to investigate complications related to the LP procedure in a large prospective multi-center feasibility LP study [8]. Such studies led amongst others to consensus LP guidelines to minimize risks and maximize diagnostic gain [9]. Another example of a standardization initiative is the Global Biomarkers Standardization Consortium (GBSC), with the goal to gather key researchers, clinicians, and industry, regulatory and government leaders in $\mathrm{AD}$ to achieve consensus on the best ways to standardize and validate biomarker tests for use in clinical practices around the world [27, 36]. In addition, the AD Neuroimaging Initiative (ADNI), the Alzheimer Biomarker Standardization Initiative (ABSI), and the JPND BIOMARKPD consortium have been launched. The Alzheimer's Association 
launched an international external Quality Control (AA QC) program (2009) [36], coordinated by the Clinical Neurochemistry Laboratory in Mölndal, Sweden, and has put forth the aim to standardize CSF biomarker analyses and monitor analytical variability for $A \beta$ and tau proteins in CSF between both research and clinical laboratories [34]. Unfortunately, the overall variability remained too high to allow assignment of universal biomarker cut-off values [36]. Further standardization of laboratory procedures and improvement of operator performance is required.

The running international standardization and harmonization efforts are very valuable as these initiatives are essential to ensure reproducible and consistent biomarker measurements, to reduce discussion in the $\mathrm{AD}$ field regarding biomarker values and clinical interpretation of the biomarker results, and to facilitate worldwide comparison of CSF biomarkers.

\section{Contributions and relevance of standardization and harmonization efforts}

The overall goal of all these projects is (1) to detect AD at the earliest stage possible and identify ways to track the disease through CSF biomarkers, (2) to support advances in $\mathrm{AD}$ intervention, prevention, and treatment (through new diagnostic methods), and (3) to centralize data access. These initiatives have led to consensus publications on the procedure for LP/CSF sampling [9], standardization of preanalytical factors [34, 37-39], immunoassay method validation and standardization for specific biomarkers $[35,40,41]$, and the clinical use of AD CSF biomarkers [29, 42, 43].

One of the most important recommendations with a significant effect on pre-analytical variability concerns the standardization of the vial in which CSF is collected and shipped to the reference lab. It was already well known that adsorption of $A \beta_{1-42}$ on a glassy or polystyrene vial wall causes false-low $A \beta_{1-42}$ values. Therefore, the use of polypropylene vials is indispensable, but differences due to adsorption of $\mathrm{A} \beta_{1-42}$ may also occur between different brands of polypropylene vials [38, 44, 45].

Importantly, although pre-analytical and analytical variations in the concentration of CSF AD biomarkers are kept to a minimum by means of these initiatives, a recent study pointed out that simulated biomarker variability by means of shifts of $\pm 20 \%$ in one of the three core CSF biomarkers has limited impact on the clinical accuracy of AD CSF biomarkers in MCI and autopsy-confirmed AD patients when using the IWG-2 criteria [46].

\section{Clinical indications for using the Alzheimer's disease cerebrospinal fluid biomarker panel}

\section{To increase the diagnostic accuracy in case of suspected Alzheimer's disease}

Although AD diagnostics increasingly become biomarker-based, this does not imply that every patient with suspected AD needs an LP with the exception of patients with early-onset dementia, in whom LP and CSF biomarker analysis should be routinely performed [29]. Indeed, evidence from memory clinic-based studies using autopsy-confirmed dementia patients demonstrated that the diagnostic accuracy of CSF biomarkers was comparable to the diagnostic accuracy of a clinical diagnostic work-up performed in demented patients consisting of a semi-structured interview with patient and main caregiver, general physical and clinical neurological examination, blood analysis, extensive neuropsychological examination, and brain imaging [47, 48]. However, CSF biomarkers are very valuable in those cases in which the clinical diagnostic work-up is not able to discriminate between $\mathrm{AD}$ and another (non-AD) type of dementia [47, 48]. Therefore, in cases with an inconclusive clinical diagnostic work-up, leading to an ambiguous $\mathrm{AD}$ versus non-AD differential diagnosis, the AD CSF biomarker panel has an added diagnostic value. This is as well reflected by a growing number (from 238 in 2004 to $>1000$ in 2016) of CSF samples that have been referred to the UAntwerp BIODEM lab, specifically for this indication [49].

\section{To diagnose Alzheimer's disease in its earliest stages}

\section{Pre-clinical Alzheimer's disease}

The neuropathological brain lesions are present in preclinical $\mathrm{AD}$, which is reflected by altered levels of the $\mathrm{AD}$ CSF biomarkers already before the onset of symptoms, and $\mathrm{A} \beta_{1-42}$ is the earliest marker to mirror these changes $[18,50]$. This is of major importance to the health care system given the pending availability of disease-modifying drugs. Even though a CSF AD profile is much more common in patients with $\mathrm{MCI}$ and SCD, it is also seen in $28-36 \%$ of cognitively healthy elderly at the age of 85 $[15,50]$. However, in the absence of any therapeutic consequences for pre-clinical AD, CSF biomarker analyses should not be performed in asymptomatic subjects, except in consented subjects and within the context of research and clinical trials. 


\section{Prodromal Alzheimer's disease}

Patients with MCI will progress to dementia at a much higher rate than healthy elderly, which makes this an excellent study population to explore the possible predictive value of CSF biomarkers [51]. In these patients, the three CSF biomarkers $\mathrm{A} \beta_{1-42}, \mathrm{~T}$-tau, and $\mathrm{P}-\mathrm{tau}_{181}$ are strongly associated with future development of $\mathrm{AD}$ dementia, which was proven in a large prospective study with a mean follow-up period of more than 5 years [28] as well as in two multi-center studies [52, 53]. The AD CSF biomarkers can in fact identify those MCI patients who have prodromal AD. In the study of Hansson et al., the combination of CSF $A \beta_{1-42}$ and T-tau at baseline yielded sensitivity and specificity levels of 95 and $83 \%$ for clinical AD diagnosis in patients with MCI [17, 28]. A high progression rate (prodromal to dementia) was confirmed by patients with a high likelihood for AD based on the NIAAA criteria compared to patients with an intermediate or lowest likelihood for AD in a clinical setting [53].

\section{To discriminate Alzheimer's disease from other neurodegenerative and cerebrovascular brain disorders: differential diagnosis}

The assessment of $\mathrm{A} \beta_{1-42}$, T-tau, and P-tau 181 can discriminate between AD and non-AD dementias [26, 54], but they cannot be used to confirm another type of dementia. Several other brain diseases can lead to pathological values of these core AD CSF biomarkers which might lead to possible misinterpretation of the biomarker results in the absence of clinical information. An increase in T-tau is also detected after stroke [55] and in disorders with extensive and/or rapid neuronal degeneration, such as CreutzfeldtJakob's disease (CJD) [56], as opposed to other disorders with limited neuronal degeneration. For this reason, P-tau ${ }_{181}$ seems to be a more specific marker for AD [54]. Moreover, both $A \beta_{1-42}$ and T-tau are detected at intermediate levels, in between normal control and abnormal AD values [26, 27, 57, 58], in non-AD patients, especially in dementia with Lewy bodies (DLB) but also in frontotemporal dementia (FTD), vascular dementia (VaD), and CJD. To improve the discriminatory power for the differential diagnosis of dementia, additional markers, more specific to the non-AD dementia can be valuable, described below (New biomarkers specific for non-AD diseases). Another problem in using CSF biomarkers for dementia diagnosis is the inter-patient variability. Indeed, heterogeneity in the amount of plaques and tangles in AD brains exist, and the plaque and tangle load in selected neocortical areas are even known to correlate with CSF biomarker concentrations, but not with Braak stages that take into account neocortical as well as allocortical brain regions [59, 60].
To identify Alzheimer's disease in case of suspected mixed brain pathologies

The existence of co-pathologies can lead to a potential misinterpretation of CSF biomarker results. It has been confirmed in a neuropathological study that many dementia patients have brain pathologies associated with more than one type of dementia [61]. In case of non-AD dementias, such as DLB, AD co-pathology frequently occurs [62]. Furthermore, as age is a common risk factor for neurodegenerative dementias and cerebrovascular disease (CVD), many demented patients show signs of copathologies on structural brain imaging at the clinical diagnostic work-up, which is confirmed by neuropathological examination [61]. It is often difficult to judge whether the vascular lesions are main contributors to the dementia, and there is a risk of over diagnosing $\mathrm{VaD}$ based on structural brain imaging [63]. In case of doubt between $\mathrm{VaD}$ or mixed $\mathrm{AD}-\mathrm{CVD}$ pathology in dementia patients, the determination of CSF $\mathrm{A} \beta_{1-42}, \mathrm{~T}$-tau, and P-tau 181 levels is of help to confirm or exclude the AD component in the pathophysiology of the dementia syndrome [58].

\section{To diagnose Alzheimer's disease in case of a typical presentations}

$\mathrm{AD}$ is thought to progress in a fairly stereotypical manner, as brain dysfunction begins in the hippocampal region resulting in episodic memory loss as the first and most typical symptom of $\mathrm{AD}$ [13]. However, there is considerable heterogeneity in the relative involvement of different cognitive domains, and therefore, the IWG-2 criteria [13], combining biomarkers and clinical phenotypes, distinguish 'typical' [i.e., memory-led AD) from 'atypical' AD. The latter comprises visual/biparietal (posterior cortical atrophy (PCA)] [64], logopenic (language), frontal (behavioral) variants of $\mathrm{AD}$ [65], and cerebral amyloid angiopathy (CAA) [66, 67]. Though each of these syndromes is variably associated with clinical presentations of non-AD dementias, typical and atypical AD share the same core pathology and can thus be diagnosed by the three core AD CSF biomarkers [68].

\section{Future cerebrospinal fluid biomarkers for Alzheimer's disease (differential) diagnosis}

\section{New biomarkers for differential dementia diagnosis}

As mentioned before, there is an overlap in $\mathrm{A} \beta_{1-42}$ values between $\mathrm{AD}$ and non-AD dementia patients. To overcome this, other CSF biomarkers like $A \beta_{1-40}$ are 
introduced to increase clinical diagnostic accuracy. Nevertheless, $A \beta_{1-40}$ is also decreased in non-AD dementia patients, which may be explained by disease specific inter-individual variability in $A \beta$ metabolism (high or low $\mathrm{A} \beta$ production and/or clearance). Therefore, the addition of the most abundant $A \beta$ isoform, i.e., $A \beta_{1-}$ 40 into an $\mathrm{A} \beta_{1-42 /} \mathrm{A} \beta_{1-40}$ ratio, might prove to be an efficient way to diminish inter-patient variability (to control for high or low $A \beta_{1-42}$ production, irrespective of $\mathrm{AD}$ pathology) [69]. $\mathrm{A} \beta_{1-40}$ has already been shown to improve differential dementia diagnosis in patients with intermediate P-tau ${ }_{181}$ levels [57]. Increased concordance between amyloid markers (amyloid-PET scan and CSF $\mathrm{A} \beta$ ) was found in two studies when the $A \beta_{1-42} / A \beta_{1-40}$ ratio was applied compared to a CSF $A \beta_{1-42}$ concentration alone [70, 71].

DLB and other synucleinopathies, including PD, PD dementia, and multiple system atrophy, are characterized by the accumulation of the protein $\alpha$-synuclein in Lewy Bodies or glial cytoplasmic inclusions [40, 72, 73]. Although the CSF biomarkers $A \beta_{1-42}$, T-tau, and P-tau 181 have an added diagnostic value for the differential dementia diagnosis, there is a need for additional markers due to often existing co-pathology in, for instance, DLB that limits the use of the $\mathrm{AD}$ core biomarkers for differential diagnosis [62]. As $\alpha$-synuclein is the main component of Lewy bodies, it has been assessed as a biomarker for DLB [72-75]. Further research into the power of $\alpha$-synuclein as a differential dementia diagnosis biomarker should clarify its potential. Furthermore, $A \beta_{1-37}$ and $A \beta_{1-38}$ increase the accuracy to differentiate AD from FTD or DLB [69] and also, transactive response DNA binding protein 43 (TDP-43), the main disease protein component in ubiquitin-positive, tau-, and $\alpha$-synucleinnegative cytoplasmic inclusions in FTD and amyotrophic lateral sclerosis (ALS) [76]. However, TDP-43 inclusions have also been found in $\mathrm{AD}$, even with a frequency of $56 \%$ in one neuropathologically confirmed $\mathrm{AD}$ case series [77]. Its potential as a CSF biomarker remains to be determined. Another promising new biomarker is total CSF prion protein (t-PrP), to differentiate AD from CJD. Although typical AD and CJD are clinically distinguishable, atypical $\mathrm{AD}$ phenotypes may present with similar features as CJD, such as very high levels of T-tau in CSF. It has been shown that t-PrP levels are lower in CJD and increased in $\mathrm{AD}$ compared to controls, both for clinical and neuropathological confirmed cases [78]. Furthermore, in cases where 14-3-3 protein was indicative for CJD, increased levels of t-PrP reduced the number of false positive cases amongst $\mathrm{AD}$ patients. T-PrP thus has the potential to increase diagnostic accuracy in atypical $\mathrm{AD}$ patients [78].

\section{Cerebospinal fluid biomarkers that predict Alzheimer's disease progression}

Although the previously described markers have a high diagnostic value, they lack the power to predict disease progression, as they only reflect the neuropathology of $\mathrm{AD}$, reaching their maximum change at the MCI stage. Therefore, synaptic proteins, as markers for synaptic dysfunction/loss, are investigated as candidate markers for $\mathrm{AD}$ progression. The post-synaptic protein neurogranin is such a potential biomarker $[79,80]$. It has been shown that neurogranin in CSF, but not plasma, was increased in $\mathrm{AD}$ and positively correlated with CSF tau [81]. There was a negative relationship between CSF neurogranin (and tau) and CSF $A \beta_{1-42} / A \beta_{1-40}$ [81]. De Vos and coworkers were the first to show that the CSF neurogranin/BACE1 ratio, reflecting post-synaptic/pre-synaptic integrity, is related to cognitive decline [82], emphasizing the potential of neurogranin as an $\mathrm{AD}$ stage marker.

\section{Discussion}

\section{Early diagnosis or timely diagnosis?}

Recent advances in CSF analyses and other biomarkers now enable the detection of $\mathrm{AD}$ in its pre-clinical phase. This fuels the debate on how and when AD should be detected, knowing that (1) effective disease-modifying drugs are currently not available and (2) there are differences in the interests and needs of individual patients (society vs research). The individual is often best served by a timely diagnosis, which could be in the MCI phase or at the 'right' moment for the individual, while the society may benefit from population screening when pharmacological prevention of $\mathrm{AD}$ is available [51]. In the absence of disease-modifying drugs, screening is debatable and more interest may be put in case finding (screening of a subgroup of the general population based on the presence of $\mathrm{AD}$ risk factors).

For (counseling in) clinical practice as well as for (clinical) research, CSF biomarkers are of importance to identify those MCI subjects who are not suffering from AD. For (clinical) research purposes, it is important to identify (asymptomatic) subjects who are at risk to develop $\mathrm{AD}$, which is possible through $\mathrm{A} \beta$ biomarkers as amyloid changes are the first that occur within the AD continuum. By follow-up of at risk subjects, testing of new screening techniques could be performed, which should ultimately lead to a sensitive and non-invasive screening instrument. Indeed, a disadvantage of CSF biomarkers is that an LP is needed, which is invasive and might lead to post-LP 
Table 2 Recommendations for applying the core AD CSF biomarkers A $\beta_{1-42}$, T-tau, and P-tau ${ }_{181}$, for clinical diagnosis

\begin{tabular}{lll}
\hline & Perform & New \\
& CSF analysis & CSF biomarkers \\
\hline Suspected AD diagnosis & Yes \\
Early-onset dementia & No \\
No doubt in clinical diagnosis & Yes \\
Ambiguous clinical diagnosis & \\
Early AD diagnosis & Yes \\
Pre-clinical AD & No \\
Clinical research & \\
Cognitively healthy elderly & Yes \\
Prodromal AD & Yes & A $\beta_{1-42} / A \beta_{1-40}, t-P r P, A \beta_{1-37}, A \beta_{1-38}, \alpha-s y n u c l e i n$ \\
Clinical evidence for cognitive decline & \\
Differential dementia diagnosis (AD versus non-AD dementia) & No \\
Mixed dementia pathology diagnosis & Yes \\
AD as co-pathology & \\
AD versus AD-CVD & Yes \\
Atypical AD diagnosis & \\
Diagnose atypical AD variants &
\end{tabular}

$A \beta \beta$-amyloid, $A D$ Alzheimer's disease, $C S F$ cerebrospinal fluid, $C V D$ cerebrovascular disease, non- $A D$ other dementia than $\mathrm{AD}$

complications. Imaging biomarkers might overcome this limitation as these are less invasive and will result in fewer post-procedure complications. At this moment, research should focus on the development/optimization of cost-efficient screening tools to be able to identify people in the asymptomatic phase once disease-modifying drugs become available. Partly due to the advance in detection techniques, research for potential disease-modifying treatments has changed its focus from the dementia phase to the MCI phase [83] and currently also to the pre-clinical phase of AD [51].

\section{Evidence-based clinical indications for application of the Alzheimer's cerebrospinal fluid biomarker panel}

The clinical indications to analyze CSF biomarkers are (1) neurochemical confirmation of $\mathrm{AD}$ in case of clinical $\mathrm{AD}$ (increase diagnostic accuracy, which is especially but not solely needed in case of early onset), (2) neurochemical confirmation of $\mathrm{AD}$ in case of doubt between $\mathrm{AD}$ dementia and non-AD dementia (including DLB, FTLD, VaD, and CJD), (3) neurochemical confirmation of prodromal AD in case of MCI, (4) neurochemical confirmation of AD in case of psychiatric disorders (like depression or psychosis), and (5) to rule out $\mathrm{AD}$ when this is clinically indicated. Over the past 10 years, the clinical indications for referral showed a shift from neurochemical confirmation of $\mathrm{AD}$ in case of clinical $\mathrm{AD}$ to differential dementia diagnosis in case of doubt between $\mathrm{AD}$ and non-AD dementias, prodromal $\mathrm{AD}$ cases, and in case of ambiguous dementia diagnosis [29, 49].

\section{Conclusions (Table 2)}

The past decade, a lot of progress has been made with regard to standardization and harmonization of existing biomarkers for $\mathrm{AD}$, dealing with pre-analytical, analytical, and post-analytical aspects. One of the most important recommendations with a significant effect on pre-analytical variability concerns the standardization of the vial in which CSF is collected and shipped to the reference lab.

The validated core AD CSF biomarkers have an added value in the (early, differential) diagnosis of $\mathrm{AD}$ and related disorders, including mixed pathologies, atypical presentations of $\mathrm{AD}$, and in case of ambiguous dementia diagnosis. Analysis of the core AD CSF biomarkers is a second line diagnostic tool and should not be routinely performed in the diagnostic work-up of dementia, except in case of early-onset dementia. The AD CSF biomarker panel cannot be used to confirm clinical diagnosis of nonAD dementias, but should be used to confirm or exclude the diagnosis of $\mathrm{AD}$. The AD CSF biomarkers are of great help to select subjects for clinical trials with potentially disease-modifying drugs against $\mathrm{AD}$ and can thus even be used to identify asymptomatic subjects who are at risk to develop symptoms of AD. 


\section{Compliance with ethical standards}

Conflict of interest This research was in part funded by the EU/ EFPIA Innovative Medicines Initiative Joint Undertaking (EMIF Grant No. 115372); the University Research Fund of the University of Antwerp; the Flemish Impulse Financing of Networks for Dementia Research (VIND); and unrestrictive research grants from Janssen Pharmaceutica NV and ADx Neurosciences. Sebastiaan Engelborghs has received unrestricted research grants from Janssen Pharmaceutica NV and ADx Neurosciences (paid to institution). Ellis Niemantsverdriet, Sara Valckx, and Maria Bjerke report no conflict of interest.

Ethical approval This article does not contain any studies with human participants or animals performed by any of the authors.

\section{Informed consent None.}

Open Access This article is distributed under the terms of the Creative Commons Attribution 4.0 International License (http://crea tivecommons.org/licenses/by/4.0/), which permits unrestricted use, distribution, and reproduction in any medium, provided you give appropriate credit to the original author(s) and the source, provide a link to the Creative Commons license, and indicate if changes were made.

\section{References}

1. Han JW, Kim TH, Lee SB, Park JH, Lee JJ, Huh Y, Park JE, Jhoo JH, Lee DY, Kim KW (2012) Predictive validity and diagnostic stability of mild cognitive impairment subtypes. Alzheimer's Dement 8(6):553-559. doi:10.1016/j.jalz.2011.08.007

2. Koepsell TD, Monsell SE (2012) Reversion from mild cognitive impairment to normal or near-normal cognition: risk factors and prognosis. Neurology 79(15):1591-1598. doi:10.1212/WNL. 0b013e31826e26b7

3. Palmer K, Backman L, Winblad B, Fratiglioni L (2008) Mild cognitive impairment in the general population: occurrence and progression to Alzheimer disease. Am J Geriatr 16(7):603-611. doi:10.1097/JGP.0b013e3181753a64

4. Petersen RC (2016) Mild cognitive impairment. Continuum 22 (2 Dementia):404-418. doi:10.1212/CON.0000000000000313

5. Jessen F, Amariglio RE, van Boxtel M, Breteler M, Ceccaldi M, Chetelat G, Dubois B, Dufouil C, Ellis KA, van der Flier WM, Glodzik L, van Harten AC, de Leon MJ, McHugh P, Mielke MM, Molinuevo JL, Mosconi L, Osorio RS, Perrotin A, Petersen RC, Rabin LA, Rami L, Reisberg B, Rentz DM, Sachdev PS, de la Sayette V, Saykin AJ, Scheltens P, Shulman MB, Slavin MJ, Sperling RA, Stewart R, Uspenskaya O, Vellas B, Visser PJ, Wagner M (2014) A conceptual framework for research on subjective cognitive decline in preclinical Alzheimer's disease. Alzheimer's Dement 10(6):844-852. doi:10.1016/j.jalz.2014.01. 001

6. Petersen RC (2004) Mild cognitive impairment as a diagnostic entity. J Intern Med 256(3):183-194. doi:10.1111/j.1365-2796. 2004.01388.x

7. McKhann GM, Knopman DS, Chertkow H, Hyman BT, Jack CR Jr, Kawas CH, Klunk WE, Koroshetz WJ, Manly JJ, Mayeux R, Mohs RC, Morris JC, Rossor MN, Scheltens P, Carrillo MC, Thies B, Weintraub S, Phelps CH (2011) The diagnosis of dementia due to Alzheimer's disease: recommendations from the National Institute on Aging-Alzheimer's Association workgroups on diagnostic guidelines for Alzheimer's disease. Alzheimer's Dement 7(3):263-269. doi:10.1016/j.jalz.2011.03.005
8. Duits FH, Martinez-Lage P, Paquet C, Engelborghs S, Lleo A, Hausner L, Molinuevo JL, Stomrud E, Farotti L, Ramakers IHGB, Tsolaki M, Skarsgard C, Astrand R, Wallin A, Vyhnalek M, Holmber-Clausen M, Forlenza OV, Ghezzi L, Ingelsson M, Hoff EI, Roks G, de Mendonca A, Papma JM, Izagirre A, Taga M, Struyfs H, Alcolea DA, Frolich L, Balasa M, Minthon L, Twisk JWR, Persson S, Zetterberg H, van der Flier WM, Teunissen CE, Scheltens P, Blennow K (2016) Performance and complications of lumbar puncture in memory clinics: results of the multicenter lumbar puncture feasibility study. Alzheimers Dement 12(2):154-163. doi:10.1016/j.jalz.2015.08.003

9. Engelborghs S, Niemantsverdriet E, Struyfs H, Blennow K, Brouns R, Comabella M, Dujmovic I, Van der Flier WM, Froelich L, Galimberti D, Gnanapavan S, Hemmer B, Hoff EI, Hort J, Iacobaeus $\mathrm{E}$, Ingelsson $\mathrm{M}$, de Jong FJ, Jonsson M, Khalil M, Kuhle J, Lleo A, De Mendonca A, Molinuevo JL, Nagels G, Paquet C, Parnetti L, Roks G, Rosa-Neto P, Scheltens P, Skarsgard C, Stomrud E, Tumani H, Visser PJ, Wallin A, Winblad B, Zetterberg H, Duits F, Teunissen C (2017) Consensus guidelines for lumbar puncture in patients with neurological diseases. Alzheimer's Dement Diagn Assess Dis Monit 8:111-126

10. McKhann G, Drachman D, Folstein M, Katzman R, Price D, Stadlan EM (1984) Clinical diagnosis of Alzheimer's disease: report of the NINCDS-ADRDA Work Group under the auspices of Department of Health and Human Services Task Force on Alzheimer's Disease. Neurology 34(7):939-944

11. Knopman DS, DeKosky ST, Cummings JL, Chui H, CoreyBloom J, Relkin N, Small GW, Miller B, Stevens JC (2001) Practice parameter: diagnosis of dementia (an evidence-based review). Report of the Quality Standards Subcommittee of the American Academy of Neurology. Neurology 56(9):1143-1153

12. Albert MS, DeKosky ST, Dickson D, Dubois B, Feldman HH, Fox NC, Gamst A, Holtzman DM, Jagust WJ, Petersen RC, Snyder PJ, Carrillo MC, Thies B, Phelps CH (2011) The diagnosis of mild cognitive impairment due to Alzheimer's disease: recommendations from the National Institute on Aging-Alzheimer's Association workgroups on diagnostic guidelines for Alzheimer's disease. Alzheimer's Dement 7(3):270-279. doi:10. 1016/j.jalz.2011.03.008

13. Dubois B, Feldman HH, Jacova C, Hampel H, Molinuevo JL, Blennow K, DeKosky ST, Gauthier S, Selkoe D, Bateman R, Cappa S, Crutch S, Engelborghs S, Frisoni GB, Fox NC, Galasko D, Habert MO, Jicha GA, Nordberg A, Pasquier F, Rabinovici G, Robert P, Rowe C, Salloway S, Sarazin M, Epelbaum S, de Souza LC, Vellas B, Visser PJ, Schneider L, Stern Y, Scheltens P, Cummings JL (2014) Advancing research diagnostic criteria for Alzheimer's disease: the IWG-2 criteria. Lancet Neurol 13(6):614-629. doi:10.1016/S1474-4422(14)70090-0

14. Sperling RA, Aisen PS, Beckett LA, Bennett DA, Craft S, Fagan AM, Iwatsubo T, Jack CR Jr, Kaye J, Montine TJ, Park DC, Reiman EM, Rowe CC, Siemers E, Stern Y, Yaffe K, Carrillo MC, Thies B, Morrison-Bogorad M, Wagster MV, Phelps CH (2011) Toward defining the preclinical stages of Alzheimer's disease: recommendations from the National Institute on AgingAlzheimer's Association workgroups on diagnostic guidelines for Alzheimer's disease. Alzheimer's Dement 7(3):280-292. doi:10. 1016/j.jalz.2011.03.003

15. De Meyer G, Shapiro F, Vanderstichele H, Vanmechelen E, Engelborghs S, De Deyn PP, Coart E, Hansson O, Minthon L, Zetterberg H, Blennow K, Shaw L, Trojanowski JQ, AsDN Initi (2010) Diagnosis-independent Alzheimer disease biomarker signature in cognitively normal elderly people. Arch Neurol Chicago 67(8):949-956

16. Consensus report of the working group on:"Molecular and biochemical markers of Alzheimer's disease". The Ronald and Nancy Reagan Research Institute of the Alzheimer's Association 
and National Institute on Aging Working Group. (1998). Neurobiology of aging 19 (2):109-116

17. Olsson B, Lautner R, Andreasson U, Ohrfelt A, Portelius E, Bjerke M, Holtta M, Rosen C, Olsson C, Strobel G, Wu E, Dakin K, Petzold M, Blennow K, Zetterberg H (2016) CSF and blood biomarkers for the diagnosis of Alzheimer's disease: a systematic review and meta-analysis. Lancet Neurol 15(7):673-684. doi:10. 1016/S1474-4422(16)00070-3

18. Jansen WJ, Ossenkoppele R, Knol DL, Tijms BM, Scheltens P, Verhey FR, Visser PJ, Amyloid Biomarker Study G, Aalten P, Aarsland D, Alcolea D, Alexander M, Almdahl IS, Arnold SE, Baldeiras I, Barthel H, van Berckel BN, Bibeau K, Blennow K, Brooks DJ, van Buchem MA, Camus V, Cavedo E, Chen K, Chetelat G, Cohen AD, Drzezga A, Engelborghs S, Fagan AM, Fladby T, Fleisher AS, van der Flier WM, Ford L, Forster S, Fortea J, Foskett N, Frederiksen KS, Freund-Levi Y, Frisoni GB, Froelich L, Gabryelewicz T, Gill KD, Gkatzima O, GomezTortosa E, Gordon MF, Grimmer T, Hampel H, Hausner L, Hellwig S, Herukka SK, Hildebrandt H, Ishihara L, Ivanoiu A, Jagust WJ, Johannsen P, Kandimalla R, Kapaki E, KlimkowiczMrowiec A, Klunk WE, Kohler S, Koglin N, Kornhuber J, Kramberger MG, Van Laere K, Landau SM, Lee DY, de Leon M, Lisetti V, Lleo A, Madsen K, Maier W, Marcusson J, Mattsson N, de Mendonca A, Meulenbroek O, Meyer PT, Mintun MA, Mok V, Molinuevo JL, Mollergard HM, Morris JC, Mroczko B, Van der Mussele S, Na DL, Newberg A, Nordberg A, Nordlund A, Novak GP, Paraskevas GP, Parnetti L, Perera G, Peters O, Popp J, Prabhakar S, Rabinovici GD, Ramakers IH, Rami L, Resende de Oliveira C, Rinne JO, Rodrigue KM, Rodriguez-Rodriguez E, Roe CM, Rot U, Rowe CC, Ruther E, Sabri O, Sanchez-Juan P, Santana I, Sarazin M, Schroder J, Schutte C, Seo SW, Soetewey F, Soininen H, Spiru L, Struyfs H, Teunissen CE, Tsolaki M, Vandenberghe R, Verbeek MM, Villemagne VL, Vos SJ, van Waalwijk, van Doorn LJ, Waldemar G, Wallin A, Wallin AK, Wiltfang J, Wolk DA, Zboch M, Zetterberg H (2015) Prevalence of cerebral amyloid pathology in persons without dementia: a meta-analysis. Jama 313(19):1924-1938. doi:10.1001/jama.2015. 4668

19. Buchhave P, Minthon L, Zetterberg H, Wallin AK, Blennow K, Hansson O (2012) Cerebrospinal fluid levels of beta-amyloid $1-42$, but not of tau, are fully changed already 5 to 10 years before the onset of Alzheimer dementia. Arch Gen Psychiatry 69(1):98-106. doi:10.1001/archgenpsychiatry.2011.155

20. Jack CR Jr, Holtzman DM (2013) Biomarker modeling of Alzheimer's disease. Neuron 80(6):1347-1358. doi:10.1016/j.neu ron.2013.12.003

21. Savva GM, Wharton SB, Ince PG, Forster G, Matthews FE, Brayne C, Medical Research Council Cognitive F, Ageing S (2009) Age, neuropathology, and dementia. N Engl J Med 360(22):2302-2309. doi:10.1056/NEJMoa0806142

22. Ottoy J, Verhaeghe J, Niemantsverdriet E, Wyffels L, Somers C, De Roeck E, Struyfs H, Soetewey F, Deleye S, Van den Bossche T, Van Mossevelde S, Ceyssens S, Versijpt J, Stroobants S, Engelborghs S, Staelens S (2017) Validation of the semi-quantitative static SUVR method for [18F]-AV45 PET by pharmacokinetic modeling with an arterial input function. J Nucl Med. doi:10.2967/jnumed.116.184481

23. Bosco P, Redolfi A, Bocchetta M, Ferrari C, Mega A, Galluzzi S, Austin M, Chincarini A, Collins DL, Duchesne S, Marechal B, Roche A, Sensi F, Wolz R, Alegret M, Assal F, Balasa M, Bastin C, Bougea A, Emek-Savas DD, Engelborghs S, Grimmer T, Grosu G, Kramberger MG, Lawlor B, Mandic Stojmenovic G, Marinescu M, Mecocci P, Molinuevo JL, Morais R, Niemantsverdriet E, Nobili F, Ntovas K, O’Dwyer S, Paraskevas GP, Pelini L, Picco A, Salmon E, Santana I, Sotolongo-Grau O, Spiru L, Stefanova E, Popovic KS, Tsolaki M, Yener GG, Zekry D,
Frisoni GB (2017) The impact of automated hippocampal volumetry on diagnostic confidence in patients with suspected Alzheimer's disease: an EADC study. Alzheimer's Dement. doi:10. 1016/j.jalz.2017.01.019

24. Weiner MW, Veitch DP, Aisen PS, Beckett LA, Cairns NJ, Green RC, Harvey D, Jack CR Jr, Jagust W, Morris JC, Petersen RC, Saykin AJ, Shaw LM, Toga AW, Trojanowski JQ, Alzheimer's Disease Neuroimaging I (2017) Recent publications from the Alzheimer's Disease Neuroimaging Initiative: reviewing progress toward improved AD clinical trials. Alzheimer's Dement. doi:10. 1016/j.jalz.2016.11.007

25. Clark CM, Pontecorvo MJ, Beach TG, Bedell BJ, Coleman RE, Doraiswamy PM, Fleisher AS, Reiman EM, Sabbagh MN, Sadowsky CH, Schneider JA, Arora A, Carpenter AP, Flitter ML, Joshi AD, Krautkramer MJ, Lu M, Mintun MA, Skovronsky DM, Group A-AS (2012) Cerebral PET with florbetapir compared with neuropathology at autopsy for detection of neuritic amyloid-beta plaques: a prospective cohort study. Lancet Neurol 11(8):669-678. doi:10.1016/S1474-4422(12)70142-4

26. Engelborghs S, De Vreese K, Van de Casteele T, Vanderstichele H, Van Everbroeck B, Cras P, Martin JJ, Vanmechelen E, De Deyn PP (2008) Diagnostic performance of a CSF-biomarker panel in autopsy-confirmed dementia. Neurobiol Aging 29(8):1143-1159. doi:10.1016/j.neurobiolaging.2007.02.016

27. Blennow K, Hampel H, Weiner M, Zetterberg H (2010) Cerebrospinal fluid and plasma biomarkers in Alzheimer disease. Nat Rev Neurol 6(3):131-144. doi:10.1038/nrneurol.2010.4

28. Hansson O, Zetterberg H, Buchhave P, Londos E, Blennow K, Minthon L (2006) Association between CSF biomarkers and incipient Alzheimer's disease in patients with mild cognitive impairment: a follow-up study. Lancet Neurol 5(3):228-234. doi:10.1016/S1474-4422(06)70355-6

29. Molinuevo JL, Blennow K, Dubois B, Engelborghs S, Lewczuk P, Perret-Liaudet A, Teunissen CE, Parnetti L (2014) The clinical use of cerebrospinal fluid biomarker testing for Alzheimer's disease diagnosis: a consensus paper from the Alzheimer's Biomarkers Standardization Initiative. Alzheimer's Dement 10(6):808-817. doi:10.1016/j.jalz.2014.03.003

30. Le Bastard N, Aerts L, Sleegers K, Martin JJ, Van Broeckhoven C, De Deyn PP, Engelborghs S (2013) Longitudinal stability of cerebrospinal fluid biomarker levels: fulfilled requirement for pharmacodynamic markers in Alzheimer's disease. J Alzheimer's Dis 33(3):807-822. doi:10.3233/JAD-2012-110029

31. Sunderland T, Linker G, Mirza N, Putnam KT, Friedman DL, Kimmel LH, Bergeson J, Manetti GJ, Zimmermann M, Tang B, Bartko JJ, Cohen RM (2003) Decreased beta-amyloid1-42 and increased tau levels in cerebrospinal fluid of patients with Alzheimer disease. JAMA 289(16):2094-2103. doi:10.1001/jama. 289.16.2094

32. Andreasen N, Minthon L, Davidsson P, Vanmechelen E, Vanderstichele H, Winblad B, Blennow K (2001) Evaluation of CSFtau and CSF-Abeta42 as diagnostic markers for Alzheimer disease in clinical practice. Arch Neurol 58(3):373-379

33. Le Bastard N, Coart E, Vanderstichele H, Vanmechelen E, Martin JJ, Engelborghs S (2013) Comparison of two analytical platforms for the clinical qualification of Alzheimer's disease biomarkers in pathologically-confirmed dementia. J Alzheimers Dis 33(1):117-131. doi:10.3233/Jad-2012-121246

34. Bjerke M, Portelius E, Minthon L, Wallin A, Anckarsater H, Anckarsater R, Andreasen N, Zetterberg H, Andreasson U, Blennow K (2010) Confounding factors influencing amyloid Beta concentration in cerebrospinal fluid. International Journal of Alzheimer's Disease 2010

35. Bjerke M, Andreasson U, Kuhlmann J, Portelius E, Pannee J, Lewczuk P, Umek RM, Vanmechelen E, Vanderstichele H, Stoops E, Lewis J, Vandijck M, Kostanjevecki V, Jeromin A, 
Salamone SJ, Schmidt O, Matzen A, Madin K, Eichenlaub U, Bittner T, Shaw LM, Zegers I, Zetterberg H, Blennow K (2016) Assessing the commutability of reference material formats for the harmonization of amyloid-beta measurements. Clin Chem Lab Med 54(7):1177-1191. doi:10.1515/cclm-2015-0733

36. Mattsson N, Andreasson U, Persson S, Carrillo MC, Collins S, Chalbot S, Cutler N, Dufour-Rainfray D, Fagan AM, Heegaard NH, Robin Hsiung GY, Hyman B, Iqbal K, Kaeser SA, Lachno DR, Lleo A, Lewczuk P, Molinuevo JL, Parchi P, Regeniter A, Rissman RA, Rosenmann H, Sancesario G, Schroder J, Shaw LM, Teunissen CE, Trojanowski JQ, Vanderstichele H, Vandijck M, Verbeek MM, Zetterberg H, Blennow K, Alzheimer's Association QCPWG (2013) CSF biomarker variability in the Alzheimer's Association quality control program. Alzheimer's Dement 9(3):251-261. doi:10.1016/j.jalz.2013.01.010

37. Le Bastard N, De Deyn PP, Engelborghs S (2015) Importance and impact of pre-analytical variables on Alzheimer's Disease biomarker levels in cerebrospinal fluid. Clin Chem 61(5):734-743

38. del Campo M, Mollenhauer B, Bertolotto A, Engelborghs S, Hampel H, Simonsen AH, Kapaki E, Kruse N, Le Bastard N, Lehmann S, Molinuevo JL, Parnetti L, Perret-Liaudet A, SaezValero J, Saka E, Urbani A, Vanmechelen E, Verbeek M, Visser PJ, Teunissen C (2012) Recommendations to standardize preanalytical confounding factors in Alzheimer's and Parkinson's disease cerebrospinal fluid biomarkers: an update. Biomark Med 6(4):419-430. doi:10.2217/bmm.12.46

39. Vanderstichele H, Bibl M, Engelborghs S, Le Bastard N, Lewczuk P, Molinuevo JL, Parnetti L, Perret-Liaudet A, Shaw LM, Teunissen C, Wouters D, Blennow K (2012) Standardization of preanalytical aspects of cerebrospinal fluid biomarker testing for Alzheimer's disease diagnosis: a consensus paper from the Alzheimer's Biomarkers Standardization Initiative. Alzheimer's Dement 8(1):65-73. doi:10.1016/j.jalz.2011.07.004

40. Andreasson U, Perret-Liaudet A, van Doorn LJCV, Blennow K, Chiasserini D, Engelborghs S, Fladby T, Genc S, Kruse N, Kuipenj HB, Kulic L, Lewczuk P, Mollenhauer B, Mroczko B, Pametti L, Vanmechelen E, Verbeek MM, Winblad B, Zetterberg H, Koel-Simmelink M, Teunissen CE (2015) A practical guide to immunoassay method validation. Front Neurol 6

41. Kruse N, Persson S, Alcolea D, Bahl JM, Baldeiras I, Capello E, Chiasserini D, Bocchio Chiavetto L, Emersic A, Engelborghs S, Eren E, Fladby T, Frisoni G, Garcia-Ayllon MS, Genc S, Gkatzima O, Heegaard NH, Janeiro AM, Kovacech B, Kuiperij HB, Leitao MJ, Lleo A, Martins M, Matos M, Mollergard HM, Nobili F, Ohrfelt A, Parnetti L, de Oliveira CR, Rot U, SaezValero J, Struyfs H, Tanassi JT, Taylor P, Tsolaki M, Vanmechelen E, Verbeek MM, Zilka N, Blennow K, Zetterberg H, Mollenhauer B (2015) Validation of a quantitative cerebrospinal fluid alpha-synuclein assay in a European-wide interlaboratory study. Neurobiol Aging 36(9):2587-2596. doi:10.1016/j.neuro biolaging.2015.05.003

42. Herukka SK, Simonsen AH, Andreasen N, Baldeiras I, Bjerke M, Blennow K, Engelborghs S, Frisoni GB, Gabryelewicz T, Galluzzi S, Handels R, Kramberger MG, Kulczynska A, Molinuevo JL, Mroczko B, Nordberg A, Oliveira CR, Otto M, Rinne JO, Rot U, Saka E, Soininen H, Struyfs H, Suardi S, Visser PJ, Winblad B, Zetterberg H, Waldemar G (2017) Recommendations for cerebrospinal fluid Alzheimer's disease biomarkers in the diagnostic evaluation of mild cognitive impairment. Alzheimer's Dement 13(3):285-295. doi:10.1016/j.jalz.2016.09.009

43. Simonsen AH, Herukka SK, Andreasen N, Baldeiras I, Bjerke M, Blennow K, Engelborghs S, Frisoni GB, Gabryelewicz T, Galluzzi S, Handels R, Kramberger MG, Kulczynska A, Molinuevo JL, Mroczko B, Nordberg A, Oliveira CR, Otto M, Rinne JO, Rot U, Saka E, Soininen H, Struyfs H, Suardi S, Visser PJ, Winblad
B, Zetterberg H, Waldemar G (2017) Recommendations for CSF $\mathrm{AD}$ biomarkers in the diagnostic evaluation of dementia. Alzheimer's Dement 13(3):274-284. doi:10.1016/j.jalz.2016.09.008

44. Fourier A, Portelius E, Zetterberg H, Blennow K, Quadrio I, Perret-Liaudet A (2015) Pre-analytical and analytical factors influencing Alzheimer's disease cerebrospinal fluid biomarker variability. Clin Chim Acta Int J Clin Chem 449:9-15. doi:10. 1016/j.cca.2015.05.024

45. Willemse E, van Uffelen K, Brix B, Engelborghs S, Vanderstichele $\mathrm{H}$, Teunissen $\mathrm{C}$ (2017) How to handle adsorption of cerebrospinal fluid amyloid-beta (1-42) in laboratory practice? Identifying problematic handlings and resolving the issue by use of the Abeta42/Abeta40 ratio. Alzheimer's Dement. doi:10.1016/ j.jalz.2017.01.010

46. Niemantsverdriet E, Goossens J, Struyfs H, Martin JJ, Goeman J, De Deyn PP, Vanderstichele H, Engelborghs S (2016) Limited diagnostic impact of CSF biomarker variability in Alzheimer's disease. J Alzheimer's Dis 51:97-106

47. Niemantsverdriet E, Feyen BF, Le Bastard N, Martin JJ, Goeman J, De Deyn PP, Bjerke M, Engelborghs S (Submitted, 2017) Added diagnostic value of CSF biomarkers for differential dementia diagnosis in an autopsy-confirmed cohort. Alzheimer's Res Ther

48. Le Bastard N, Martin JJ, Vanmechelen E, Vanderstichele H, De Deyn PP, Engelborghs S (2010) Added diagnostic value of CSF biomarkers in differential dementia diagnosis. Neurobiol Aging 31(11):1867-1876. doi:10.1016/j.neurobiolaging.2008.10.017

49. Somers C, Struyfs H, Goossens J, Niemantsverdriet E, Luyckx J, De Roeck N, De Roeck E, De Vil B, Cras P, Martin JJ, De Deyn PP, Bjerke M, Engelborghs S (2016) A decade of cerebrospinal fluid biomarkers for Alzheimer's disease in Belgium. J Alzheimer's Dis 54(1):383-395. doi:10.3233/JAD-151097

50. Toledo JB, Zetterberg H, van Harten AC, Glodzik L, MartinezLage P, Bocchio-Chiavetto L, Rami L, Hansson O, Sperling R, Engelborghs S, Osorio RS, Vanderstichele H, Vandijck M, Hampel H, Teipl S, Moghekar A, Albert M, Hu WT, Argiles JAM, Gorostidi A, Teunissen CE, De Deyn PP, Hyman BT, Molinuevo JL, Frisoni GB, Linazasoro G, de Leon MJ, van der Flier WM, Scheltens P, Blennow K, Shaw LM, Trojanowski JQ, AsD Neuroimaging (2015) Alzheimer's disease cerebrospinal fluid biomarker in cognitively normal subjects. Brain 138:2701-2715. doi:10.1093/brain/awv199

51. De Roeck EE, Engelborghs S, Dierckx E (2016) Next generation brain health depends on early Alzheimer disease diagnosis: from a timely diagnosis to future population screening. J Am Med Dir Assoc 17(5):452-453. doi:10.1016/j.jamda.2016.02.015

52. Mattsson N, Zetterberg H, Hansson O, Andreasen N, Parnetti L, Jonsson M, Herukka SK, van der Flier WM, Blankenstein MA, Ewers M, Rich K, Kaiser E, Verbeek M, Tsolaki M, Mulugeta E, Rosen E, Aarsland D, Visser PJ, Schroder J, Marcusson J, de Leon M, Hampel H, Scheltens P, Pirttila T, Wallin A, Jonhagen ME, Minthon L, Winblad B, Blennow K (2009) CSF biomarkers and incipient Alzheimer disease in patients with mild cognitive impairment. JAMA 302(4):385-393. doi:10.1001/jama.2009. 1064

53. Vos SJB, Verhey F, Frolich L, Kornhuber J, Wiltfang J, Maier W, Peters O, Ruther E, Nobili F, Morbelli S, Frisoni GB, Drzezga A, Didic M, van Berckel BNM, Simmons A, Soininen H, Kloszewska I, Mecocci P, Tsolaki M, Vellas B, Lovestone S, Muscio C, Herukka SK, Salmon E, Bastin C, Wallin A, Nordlund A, de Mendonca A, Silva D, Santana I, Lemos R, Engelborghs S, Van der Mussele S, Freund-Levi Y, Wallin AK, Hampel H, van der Flier W, Scheltens P, Visser PJ, AsDN Initi (2015) Prevalence and prognosis of Alzheimer's disease at the mild cognitive impairment stage. Brain 138:1327-1338. doi:10.1093/brain/ awv029 
54. Niemantsverdriet E, Struyfs H, Duits F, Teunissen C, Engelborghs $S$ (2015) Techniques, contraindications and complications of CSF collection procedures. In: Deisenhammer F, Sellebjerg F, Teunissen CE, Tumani H (eds) Cerebrospinal Fluid in Clinical Neurology. Springer, New York, pp 35-57

55. Hjalmarsson $\mathrm{C}$, Bjerke M, Andersson B, Blennow K, Zetterberg $\mathrm{H}$, Aberg ND, Olsson B, Eckerstrom C, Bokemark L, Wallin A (2014) Neuronal and glia-related biomarkers in cerebrospinal fluid of patients with acute ischemic stroke. J Cent Nerv Syst Dis 6:51-58. doi:10.4137/JCNSD.S13821

56. Lattanzio F, Abu-Rumeileh S, Franceschini A, Kai H, Amore G, Poggiolini I, Rossi M, Baiardi S, McGuire L, Ladogana A, Pocchiari M, Green A, Capellari S, Parchi P (2017) Prion-specific and surrogate CSF biomarkers in Creutzfeldt-Jakob disease: diagnostic accuracy in relation to molecular subtypes and analysis of neuropathological correlates of p-tau and Abeta42 levels. Acta Neuropathol 133(4):559-578. doi:10.1007/s00401-0171683-0

57. Slaets S, Le Bastard N, Martin JJ, Sleegers K, Van Broeckhoven C, De Deyn PP, Engelborghs S (2013) Cerebrospinal fluid Abeta1-40 improves differential dementia diagnosis in patients with intermediate P-tau181P levels. J Alzheimer's Dis 36(4):759-767. doi:10.3233/JAD-130107

58. Bjerke M, Zetterberg H, Edman A, Blennow K, Wallin A, Andreasson U (2011) Cerebrospinal fluid matrix metalloproteinases and tissue inhibitor of metalloproteinases in combination with subcortical and cortical biomarkers in vascular dementia and Alzheimer's disease. J Alzheimer's Dis 27(3):665-676. doi:10. 3233/JAD-2011-110566

59. Buerger K, Ewers M, Pirttila T, Zinkowski R, Alafuzoff I, Teipel SJ, DeBernardis J, Kerkman D, McCulloch C, Soininen H, Hampel H (2006) CSF phosphorylated tau protein correlates with neocortical neurofibrillary pathology in Alzheimer's disease. Brain 129(Pt 11):3035-3041. doi:10.1093/brain/aw1269

60. Engelborghs S, Sleegers K, Cras P, Brouwers N, Serneels S, De Leenheir E, Martin JJ, Vanmechelen E, Van Broeckhoven C, De Deyn PP (2007) No association of CSF biomarkers with APOEepsilon4, plaque and tangle burden in definite Alzheimer's disease. Brain 130(Pt 9):2320-2326. doi:10.1093/brain/awm136

61. De Reuck J, Deramecourt V, Cordonnier C, Leys D, Pasquier F, Maurage CA (2011) Prevalence of small cerebral bleeds in patients with a neurodegenerative dementia: a neuropathological study. J Neurol Sci 300(1-2):63-66. doi:10.1016/j.jns.2010.09.031

62. Slaets S, Le Bastard N, Theuns J, Sleegers K, Verstraeten A, De Leenheir E, Luyckx J, Martin JJ, Van Broeckhoven C, Engelborghs S (2013) Amyloid pathology influences abeta1-42 cerebrospinal fluid levels in dementia with lewy bodies. J Alzheimer's Dis 35(1):137-146. doi:10.3233/JAD-122176

63. Niemantsverdriet E, Feyen BF, Le Bastard N, Martin JJ, Goeman J, De Deyn PP, Engelborghs S (2015) Overdiagnosing vascular dementia using structural brain imaging for dementia work-up. J Alzheimer's Dis. doi:10.3233/JAD-142103

64. Crutch SJ, Lehmann M, Schott JM, Rabinovici GD, Rossor MN, Fox NC (2012) Posterior cortical atrophy. Lancet Neurol 11(2):170-178. doi:10.1016/S1474-4422(11)70289-7

65. Gorno-Tempini ML, Hillis AE, Weintraub S, Kertesz A, Mendez M, Cappa SF, Ogar JM, Rohrer JD, Black S, Boeve BF, Manes F, Dronkers NF, Vandenberghe R, Rascovsky K, Patterson K, Miller BL, Knopman DS, Hodges JR, Mesulam MM, Grossman M (2011) Classification of primary progressive aphasia and its variants. Neurology 76(11):1006-1014. doi:10.1212/WNL. 0b013e31821103e6

66. Verbeek MM, Kremer BP, Rikkert MO, Van Domburg PH, Skehan ME, Greenberg SM (2009) Cerebrospinal fluid amyloid beta(40) is decreased in cerebral amyloid angiopathy. Ann Neurol 66(2):245-249. doi:10.1002/ana.21694
67. Renard D, Castelnovo G, Wacongne A, Le Floch A, Thouvenot E, Mas J, Gabelle A, Labauge P, Lehmann S (2012) Interest of CSF biomarker analysis in possible cerebral amyloid angiopathy cases defined by the modified Boston criteria. J Neurol 259(11):2429-2433. doi:10.1007/s00415-012-6520-8

68. Paterson RW, Toombs J, Slattery CF, Nicholas JM, Andreasson U, Magdalinou NK, Blennow K, Warren JD, Mummery CJ, Rossor MN, Lunn MP, Crutch SJ, Fox NC, Zetterberg H, Schott JM (2015) Dissecting IWG-2 typical and atypical Alzheimer's disease: insights from cerebrospinal fluid analysis. J Neurol 262(12):2722-2730. doi:10.1007/s00415-015-7904-3

69. Struyfs H, Van Broeck B, Timmers M, Fransen E, Sleegers K, Van Broeckhoven C, De Deyn PP, Streffer JR, Mercken M, Engelborghs S (2015) Diagnostic accuracy of cerebrospinal fluid amyloid-beta isoforms for early and differential dementia diagnosis. J Alzheimers Dis 45(3):813-822. doi:10.3233/Jad-141986

70. Niemantsverdriet E, Ottoy J, Somers C, De Roeck E, Struyfs H, Soetewey F, Verhaeghe J, Van den Bosche T, Van Mossevelde S, Goeman J, De Deyn PP, Marien P, Versijpt J, Sleegers K, Van Broeckhoven C, wyffels L, Albert A, Ceyssens S, Stroobants S, Staelens S, Bjerke M, Engelborghs S (Submitted, 2017) The CSF A $\beta 1-42 / A \beta 1-40$ ratio improves concordance with amyloid-PET for diagnosing Alzheimer's disease in a clinical setting $\mathrm{J} \mathrm{Alz-}$ heimer's Dis

71. Leuzy A, Chiotis K, Hasselbalch SG, Rinne JO, de Mendonca A, Otto M, Lleo A, Castelo-Branco M, Santana I, Johansson J, Anderl-Straub S, von Arnim CA, Beer A, Blesa R, Fortea J, Herukka SK, Portelius E, Pannee J, Zetterberg H, Blennow K, Nordberg A (2016) Pittsburgh compound B imaging and cerebrospinal fluid amyloid-beta in a multicentre European memory clinic study. Brain 139(Pt 9):2540-2553. doi:10.1093/brain/ aww 160

72. Simonsen AH, Kuiperij B, El-Agnaf OM, Engelborghs S, Herukka SK, Parnetti L, Rektorova I, Vanmechelen E, Kapaki E, Verbeek M, Mollenhauer B (2016) The utility of alpha-synuclein as biofluid marker in neurodegenerative diseases: a systematic review of the literature. Biomark Med 10(1):19-34. doi:10.2217/ BMM.14.105

73. Slaets S, Vanmechelen E, Le Bastard N, Decraemer H, Vandijck M, Martin JJ, De Deyn PP, Engelborghs S (2014) Increased CSF alpha-synuclein levels in Alzheimer's disease: correlation with tau levels. Alzheimer's Dement 10(5 Suppl):S290-298. doi:10. 1016/j.jalz.2013.10.004

74. Mollenhauer B, Locascio JJ, Schulz-Schaeffer W, Sixel-Doring F, Trenkwalder C, Schlossmacher MG (2011) alpha-Synuclein and tau concentrations in cerebrospinal fluid of patients presenting with parkinsonism: a cohort study. Lancet Neurol 10(3):230-240. doi:10.1016/S1474-4422(11)70014-X

75. Parnetti L, Chiasserini D, Bellomo G, Giannandrea D, De Carlo C, Qureshi MM, Ardah MT, Varghese S, Bonanni L, Borroni B, Tambasco N, Eusebi P, Rossi A, Onofrj M, Padovani A, Calabresi P, El-Agnaf O (2011) Cerebrospinal fluid Tau/alphasynuclein ratio in Parkinson's disease and degenerative dementias. Mov Disord 26(8):1428-1435. doi:10.1002/mds.23670

76. Neumann M, Sampathu DM, Kwong LK, Truax AC, Micsenyi MC, Chou TT, Bruce J, Schuck T, Grossman M, Clark CM, McCluskey LF, Miller BL, Masliah E, Mackenzie IR, Feldman H, Feiden W, Kretzschmar HA, Trojanowski JQ, Lee VM (2006) Ubiquitinated TDP-43 in frontotemporal lobar degeneration and amyotrophic lateral sclerosis. Science 314(5796):130-133. doi:10.1126/science. 1134108

77. Arai T, Mackenzie IR, Hasegawa M, Nonoka T, Niizato K, Tsuchiya K, Iritani S, Onaya M, Akiyama H (2009) Phosphorylated TDP-43 in Alzheimer's disease and dementia with Lewy bodies. Acta Neuropathol 117(2):125-136. doi:10.1007/s00401008-0480-1 
78. Dorey A, Tholance Y, Vighetto A, Perret-Liaudet A, Lachman I, Krolak-Salmon P, Wagner U, Struyfs H, De Deyn PP, El-Moualij B, Zorzi W, Meyronet D, Streichenberger N, Engelborghs S, Kovacs GG, Quadrio I (2015) Association of cerebrospinal fluid prion protein levels and the distinction between Alzheimer disease and Creutzfeldt-Jakob disease. JAMA Neurol 72(3):267-275. doi:10.1001/jamaneurol.2014.4068

79. Thorsell A, Bjerke M, Gobom J, Brunhage E, Vanmechelen E, Andreasen N, Hansson O, Minthon L, Zetterberg H, Blennow K (2010) Neurogranin in cerebrospinal fluid as a marker of synaptic degeneration in Alzheimer's disease. Brain Res 1362:13-22. doi:10.1016/j.brainres.2010.09.073

80. Tarawneh R, D'Angelo G, Crimmins D, Herries E, Griest T, Fagan AM, Zipfel GJ, Ladenson JH, Morris JC, Holtzman DM (2016) Diagnostic and prognostic utility of the synaptic marker neurogranin in Alzheimer disease. JAMA Neurol 73(5):561-571. doi:10.1001/jamaneurol.2016.0086

81. De Vos A, Jacobs D, Struyfs H, Fransen E, Andersson K, Portelius E, Andreasson U, De Surgeloose D, Hernalsteen D,
Sleegers K, Robberecht C, Van Broeckhoven C, Zetterberg H, Blennow K, Engelborghs S, Vanmechelen E (2015) C-terminal neurogranin is increased in cerebrospinal fluid but unchanged in plasma in Alzheimer's disease. Alzheimers Dement 11(12):1461-1469. doi:10.1016/j.jalz.2015.05.012

82. De Vos A, Struyfs H, Jacobs D, Fransen E, Klewansky T, De Roeck E, Robberecht C, Van Broeckhoven C, Duyckaerts C, Engelborghs S, Vanmechelen E (2016) The CSF neurogranin/ BACE1 ratio is a potential correlate of cognitive decline in Alzheimer's Disease. J Alzheimer's Dis

83. Sevigny J, Chiao P, Bussiere T, Weinreb PH, Williams L, Maier M, Dunstan R, Salloway S, Chen T, Ling Y, O'Gorman J, Qian F, Arastu M, Li M, Chollate S, Brennan MS, Quintero-Monzon O, Scannevin RH, Arnold HM, Engber T, Rhodes K, Ferrero J, Hang Y, Mikulskis A, Grimm J, Hock C, Nitsch RM, Sandrock A (2016) The antibody aducanumab reduces Abeta plaques in Alzheimer's disease. Nature 537(7618):50-56. doi:10.1038/ nature 19323 